\title{
GYÓGYSZERTÁRI KÉSZLET OPTIMALIZÁLÁS A FOGYÁSADATOK FÜGGVÉNYÉBEN
}

\author{
Gál József - Szentpéteri Zoltán - Rafael Bence
}

\begin{abstract}
Absztrakt: Napjainkban Magyarországon több mint 5000 törzskönyvezett gyógyszer van forgalomban, emellett a gyógyszernek nem minősülő egyéb termékek száma naponta folyamatosan növekszik. A készítmények között van olyan, amit egy átlagos patikában naponta több tucatszor keresnek, de olyan termékre is akad példa, amire évi egyszer lenne csak igény. A heterogén fogyási adatok, valamint a forgalmazott szerek robbanásszerü növekedésének köszönhetően a gyógyszertáraknak egyre nagyobb logisztikai kihívást jelent, hogy a fogyasztói igényeket teljes mértékben, azonnal ki tudják elégíteni. A szektorra jellemző élesedő versenyhelyzet, patikák közötti konkurenciaharc azonban mindinkább kikényszeríti a gyógyszertáraktól a lehető legracionálisabb készlettervezést, ami figyelembe veszi az aktuális keresletet, de kerüli a gazdaságilag veszélyes felesleges készlethalmozást.
\end{abstract}

Abstract: Nowadays there are more than 5,000 registered medicine in Hungary and the number of other medicinal products every day is more average 20 than previous day. The consumer's data of products are very heterogeneous. It is an important logistics task to satisfy the demands of consumers immediately. Increasing competition in the drug sector, competition between pharmacies forces the most rational pooling, avoiding the unnecessary pool stacking.

Kulcsszavak: gyógyszer, készlet, kereslet, versenyhelyzet, patika

Keywords: medicine, stock, demand, competition, pharmacy

\section{Bevezetés}

Magyarországon több mint 2300 közforgalmú gyógyszertár müködik (1.ábra), mely gondoskodik a 9,8 millió lakos folyamatos gyógyszerellátásáról. (A gyógyszertárak száma Magyarországon, 2017.10.14.)

A közforgalmú gyógyszertárak legfontosabb feladata az adekvát népességi egészségügyi felvilágosítás, tanácsadás mellett, a biztonságos lakossági gyógyszerellátás folyamatos biztosítása. Ezeket a fontos feladatokat - természetesen - egy gyógyszertár csak megfelelö gazdasági háttér esetén tudja ellátni. A gazdaságos müködés egyik legfontosabb kritériuma pedig a lehető legracionálisabb készletgazdálkodás. A gyógyszertár forgalmazott termékeit legtöbbször a gyógyszer nagykereskedőktől vásárolja, ritkábban a termék közvetlen gyártójának képviseletétől. Magyarországon a gyógyszernagykereskedelmi piac 85 százalékát 3 nagy cég, a Hungaropharma, Phoenix és a Teva fedi le. (Átalakuló gyógyszertárak, 2017.10.14.) Ezekröl elmondható, hogy akár naponta többször szállítanak, ami jelentős segítséget nyújt a patikáknak ahhoz, hogy minél kevesebb ideig álljon a pénzük az eladni kívánt termékekben. A nagykereskedő a terméket vagy a termék gyártójától, vagy egy másik nagykereskedőtől szerzi be. A gyógyszertárak egymással kereskedése szigorúan tilos. 


\section{1. ábra: A gyógyszertárak száma Magyarországon}

\section{A gyógyszertárak száma Magyarországon (1990-2015)}

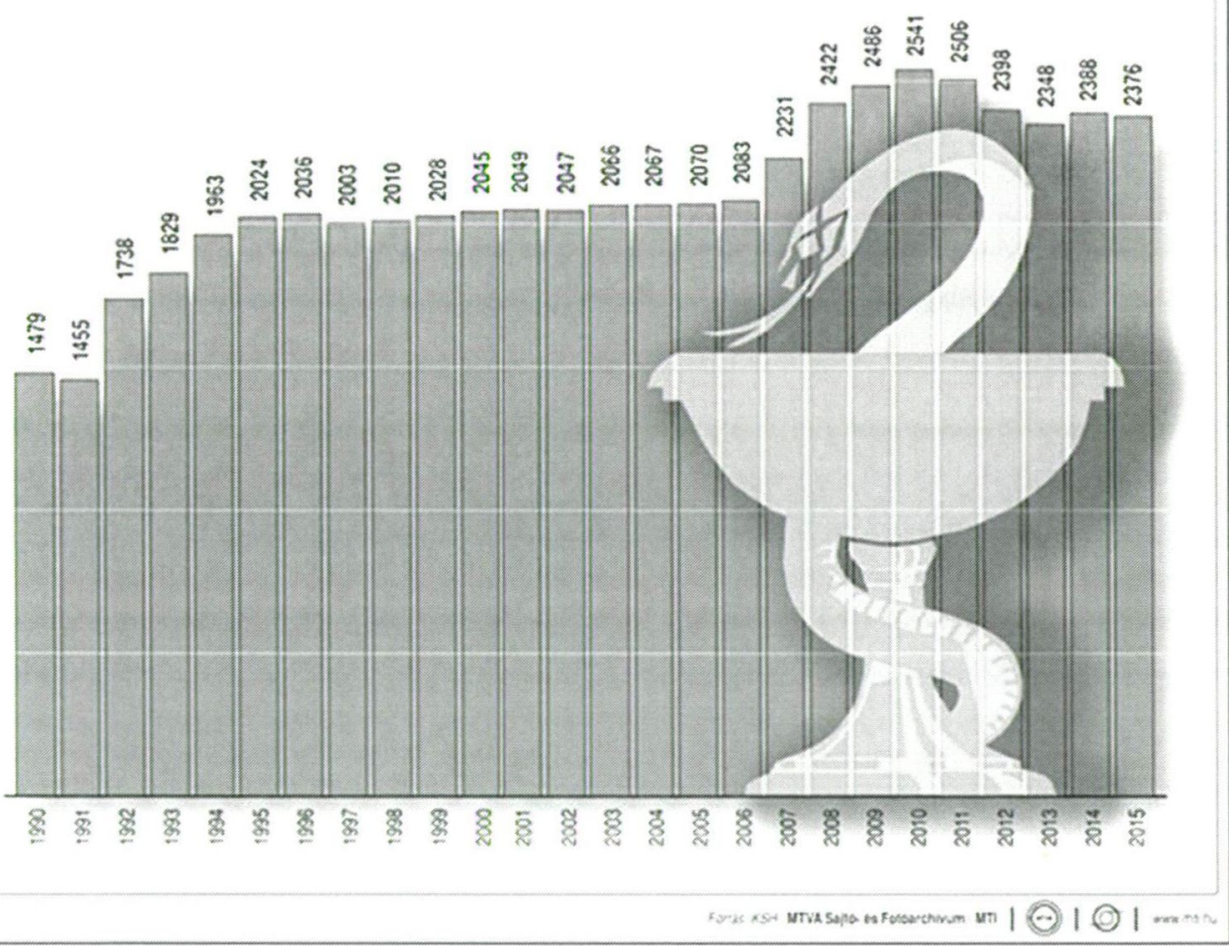

Forrás: https://profitline.hu/A-gyogyszertarak-szama-Magyarorszagon---abra-358363?abra=1

(2017.10.14.)

\section{Anyag és módszer}

A készletgazdálkodás nem csupán a termelésben, hanem a szolgáltatások piacán is egyre fontosabb tényezővé válik. Egyik oldalról megjelenik a vevői igény, amely időnként nehezen prognosztizálható, illetve magában hordozza az egészséggazdaság azon specialitását, hogy a felhasználó maga a páciens, viszont a keresletet leginkább - az orvos jelenti. Mind ezek mellett a termékeknek felhasználhatósági ideje is van, melyet szigorúan figyelembe kell venni. Tanulmányunkban ezt a speciális helyzetet, készletgazdálkodási néhány összefüggését vizsgáljuk, részben a szakirodalom, részben gyakorlati példa alapján.

\section{A gyógyszerellátási lánc}

A gyógyszertárakban forgalmazható termékek jogszabályban szigorúan rögzítettek. 


\section{1. táblázat: Csak gyógyszertárban forgalmazható termékek}

Forgalomba hozatalra engedélyezett humán gyógyszerek

A kizárólag gyógyszertári forgalmazásra engedélyezett gyógyszernek nem minősülő gyógyhatású készítmények

Magisztrális gyógyszerkészítmények (egyedi, Gyógyszerkönyv, FoNo)

Egyedi igénylésü" gyógyszerek

A gyógyászati célra engedélyezett gyógyszeranyagok, növényi/állati) drogok

Azok az anyatej-helyettesítő, -kiegészítő és speciális gyógyászati célra szánt tápszerek, amelyek árához - ha az OEP tb-támogatást állapított meg - támogatást vesznek igénybe.

Forrás: 2/2008. (I. 8.) EüM rendelet a gyógyszertárban forgalmazható, valamint kötelezően készletben tartandó termékekröl (2017.10.15.)

\section{2. táblázat: Gyógyszertárakban is forgalmazható termékek}

gyógyászati segédeszközök

orvosi kézimüszerek, eszközök

beteg- és csecsemőápolási cikkek

sebészeti varróanyagok, kötszerek

orvosi laborvizsgálati vegyszerek

(nem radioaktív) in vitro diagnosztikumok

fertőtlenítőszerek

a nem csak gyógyszertári forgalmazásra engedélyezett gyógyszernek nem minősülő gyógyhatású készítmények

gyógyvizek

gyógyteák

(külön engedély birtokában!) a törzskönyvezett állatgyógyászati készítmények és premixek

rovarcsípést megelőző és kezelő külsőleges szerek

tápszerek

kozmetikai készítmények (az adott rendeletre hivatkozva)

étrendi kiegészítők

közegészségügyi vizsgálati tartályok

kontaktlencse tisztításához és tárolásához szükséges folyadékok, edények

csecsemö- és gyermektápláláshoz szükséges eszközök

szoptatási kellékek

nyomdai vagy elektronikus úton elöállított, egészségügyi felvilágosító, tájékoztató, egészséges életmóddal kapcsolatos, a gyógyszerészi gondozást támogató könyvek, kiadványok (az ÁNTSZ illetve a Nemzeti Egészségvédelmi Intézet által egészségügyinek nyilvánított) - kiadványok

Forrás: 2/2008. (I. 8.) EüM rendelet a gyógyszertárban forgalmazható, valamint kötelezöen készletben tartandó termékekröl (2017.10.15.)

Az 1. táblázatban található a csak gyógyszertárban forgalmazható szerek listája, majd a 2. táblázatban a gyógyszertárakban is forgalmazható termékek köre. A 
listákból kitünik, hogy mennyire széles a gyógyszertárakkal szemben támasztott fogyasztói igény. (Gyógyszer adatbázis 2017.10.14, Gyógytermék adatbázis 2017.10.14.)

Gyógyszertári készletek fogalma, csoportosítása. A gyógyszertári készlet alapvetően meghatározza egy patika jövedelmezőségét. A jobb kezelhetőség, áttekinthetőség érdekében érdemes a készletünket strukturálni (Kalló $\mathrm{N}$. 2017.10.15.) az alábbi csoportosítás:

f) Biztonsági készlet: A folyamatos lakossági ellátáshoz szükséges készlet, ez általában 10-20 napi fogyást jelent, a patika forgalmától függően.

g) Kritikus készlet: Az a készletmennyiség, melynek elérésekor haladéktalanul intézkedni kell a készlet pótlásáról.

h) Folyó készlet: Két utánpótlási időpont közötti idő intervallumban szükséges készlet.

i) Optimum készlet: A biztonsági készlet és folyókészlet együttese. A készlet gazdaságosan nem emelkedhet e szint fölé.

j) Normán felüli készlet: Az a mennyiség, amellyel a készlet meghaladja az optimum készletet.

\section{Eredmények és értékelésük}

A gyógyszertári készletgazdálkodás módjai. A patikai készletünk megfelelő szinten tartását 4 különböző módszerrel tudjuk megvalósítani. Ezek a következők (Hankó Z., Sohajda A., 2017.10.14.):

14. Egyenlő időközönként egy adott szintre feltölteni a készletet. Ezt olyan stabil, nagy forgalomú készítmény esetén érdemes használni, ahol nincs gyártói kedvezmény, nagy biztonsággal beszerezhető és előfordulhat a forgalom hektikus mozgása.

15. Egyenlő időközönként ugyanannyit rendelünk a termékből. Ez olyan nagy forgalmú termékek esetén tanácsos módszer, ahol szintén nincs gyártói akció, de a forgalom hektikus mozgása kizárt.

16. Állandó mennyiség rendelése meghatározott szint elérése esetén. Ez a gyártói akciós termékek alapvető rendelési elve.

17. A készletet meghatározott szintre töltjük egy meghatározott szintre való csökkenés esetén. Ezzel a módszerrel töltjük föl a készletünket a kritikus szintről az optimális szintre. Gyakori módszer, de a termék jellege nagyban befolyásolja mennyi is az a bizonyos, optimális szint.

$\mathrm{Az}$ előző pontokban ismertetett készletezési irányelvet felhasználva szeretnénk néhány gondolatot megosztani a különböző fogyású gyógyszerek készletének optimalizálásáról:

18. Nagy fogyású termékek: Amennyiben lehetséges, mindig figyeljük a gyártói akciókat, hogy nagy kedvezménnyel jelentős mennyiséget tudjunk beszerezni, bár tekintettel kell lennünk saját tárolási kapacitásunkra is. Optimum készlet tartása a fỏ cél. Fontos, hogy kövessük a tendenciát, mert lehetséges, hogy a jelenleg keresett termék kimegy a divatból, és normán felüli készletként rajtunk marad. 
19. Átlagos fogyású termék: Ezekkel viszonylag könnyű dolgunk van, általában a napi fogyásunkat rendeljük, töltjük vissza belöle. Fontos, hogy a kritikus szint alá soha ne engedjük készletünket, viszont kerüljük a felesleges készlethalmozást, a trendekre, divatra, esetleges reklámhatásra is kiemelt figyelmet kell fordítani. Mindezek mellett a termék szezonalitása is elöfordulhat, ami kilengéseket jelent az egyébként átlagos fogyási adat ellenére is.

20. Ritka fogyású termék: Szórványos fogyás jellemző rájuk, nem rajtuk realizáljuk árréstömegünk nagy részét, de a patika presztízsét nagyban növelheti a minél szélesebb termékkínálat. Idetartoznak azok a gyógyszerek, melyeket összesen egy beteg szed és minden hónapban nálunk váltja ki azt. A drágább szereknél érdemes kommunikálni a beteggel, hogy szóljon előző nap telefonon, hogy jön a gyógyszeréért, így segíthető a racionális készletezés. Amikor olyan gyógyszert keresnek, mely nincs készleten, mindig alaposan nézzünk utána esetleg helyettesíthető-e valami mással a raktárunkról? A gyógyhatású és egyéb termékeknél is fontos, hogy lefedjünk minden betegség-tünetcsoportot, hogy alternatívát tudjunk nyújtani egy-egy szokatlanabb igénynek is. Mindig használjuk ki a nagykereskedők rugalmas szállítását, meggyőző tud lenni a vásárló számara sok esetben az, hogy a kívánt termék délutánra, vagy holnapra már készleten lesz.

21. Hiánycikkek: Sokszor előfordul, hogy gyártói vagy egyéb okokból egy termék hiánycikké válik, akár több hétig, hónapig is beszerezhetetlennek bizonyul. Bármely termékböl válhat hiánycikk, ám néhány szerrel kimondottan gyakran előfordul. Az ilyen termékeknek a viszonylag nagyobb készleten tartása segítheti betegkörünk növelését, nagy vonzerő tud lenni a vásárló számára, ha már csak nálunk tudja megvásárolni az elérhetetlennek hitt gyógyszerét.

\section{5. Összegzés, záró gondolatok}

A közvetlen lakossági gyógyszerellátás a közforgalmú gyógyszertárak legfontosabb feladata. Ez nem mindig egyszerü feladat, mert a gyógyszertárban forgalmazott termékek köre rendkívül széles. A gyógyszerellátási lánc utolsó szeme a gyógyszertár, melynek döntő szerepe van abban, hogy a beteg milyen gyorsan jut a gyógyszeréhez. A gyógyszertárak gazdaságos müködtetésének alappillére a racionális készletezés. A készletezés logisztikájának jobb áttekinthetősége érdekében a gyógyszertári készletet különbözö ismérvek alapján csoportosítani, tipizálni érdemes. A készletgazdálkodás alapja az a logisztikai iránymutatás, hogy milyen elv szerint töltjük fel a különböző típusú készleteinket. A gyakorlatban számos ökölszabályt alkalmazunk a különböző fogyású termékek optimális készletének folyamatos fenntartásához, azonban a tudományos készletezési modellek bevezetése a mindennapi munkába ennél hatékonyabb lenne. Fontos feladat lehetne, hogy ez a fajta igény - hatékonyabb szoftveres támogatással - a kisebb és a nagyobb patikák mindennapi munkájának részévé váljon. 


\section{Irodalomjegyzék}

2/2008. (I. 8.) EüM rendelet a gyógyszertárban forgalmazható, valamint kötelezōen készletben tartandó termékekröl. <https://net.jogtar.hu/jr/gen/hjegy_doc.cgi? docid=a0800002.eum> (2017.10.15.)

A gyógyszertárak száma Magyarországon. <https://profitline.hu/A-gyogyszertarak-szamaMagyarorszagon---abra-358363?abra=1> (2017.10.14.)

Átalakuló gyógyszertárak. <https://haszon.hu/archivum/1566-atalakulo-gyogyszertarak.html> (2017.10.14.)

Gyógyszer adatbázis. <https://www.ogyei.gov.hu/gyogyszeradatbazis/> (2017.10.14.)

Gyógytermék adatbázis. <https://www.ogyei.gov.hu/gyogytermek_adatbazis/> (2017.10.14.)

Hankó Z., Sohajda A.: Gyógyszertárak gazdálkodásának alapjai. MGYK. <http://docplayer.hu/1636221-Gyogyszertarak-gazdalkodasanak-alapjai-dr-hanko-zoltan-drsohajda-attila-mgyk.html> (2017.10.14.)

Kalló N. (é. n.): A készletgazdálkodás alapjai. BME MVT, <http://www.uti.bme. hu/tantargyak?p_p_id=TantargyLista_WAR_bmeuti\&p_p_lifecycle=2\&p_p_state=normal\&p_ p_mode=view\&p_p_resource_id=download\&p_p_cacheability=cacheLevelPage\&_TantargyLi sta_WAR_bmeuti_id=14024\&_TantargyLista_WAR_bmeuti_id=7276\&_TantargyLista_WAR _bmeuti_action=showTantargy $>(2017.10 .15$.) 